\title{
THE ROLE OF SOME ANTIOXIDANTS ON ALLEVIATION THE HARMFUL EFFECTS OF SALINITY ON GROWTH AND YIELD OF WHEAT (Triticum aestivum L.) PLANTS
}

Farouk, $\mathrm{S}$.

Agric. Botany Dept., Fac. Agric., Mans. Univ., Mansoura, Egypt. gadalla@mans.edu.eg

\begin{abstract}
Salt stress up to $11.5 \mathrm{dSm}^{-1}$ impaired wheat growth by reducing shoot dry weight, shoot length, number of tillers, and leaf number per plant. Imposition of salt stress also had adverse effects on flag leaf nitrogen and phosphorous content and membrane stability index percentage, and yield as well as its components (spike length, number of spikelet per spike, grain number per spike, grain weight per spike and 100 grain weight), in addition quality of grains (carbohydrates, protein, phosphorous and potassium percentage).

Application of both antioxidants increased significantly all growth and yield characteristics as well as improvement root structure. Moreover, salt induced reduction in growth and yield and its quality ameliorated by exogenously applied antioxidants, in particular, ascorbic acid (AsA) due to increasing all mentioned characters as compared to untreated plants under corresponding salinity level. Anatomically, increasing salinity levels decreased thickness of adventitious root, vascular cylinder, and thickness of either epidermis or metaxylem vessels. Treatment with either ascorbic acid or a-tocopherol at $100 \mathrm{mg} / \mathrm{L}$ and their interactions with salinity increased all the above mentioned parameters in both nonsalinized and salinized plants. Ascorbic acid is the most effective in this concern.

It could be recommended to spray wheat plants grown under salinity stress with ascorbic or $\alpha$-tocopherol to overcome destructive effect of salinity after 40 and 50 days from sowing.

Keywords: Ascorbic aid, a-tocopherol, soil salinity, growth, yield, wheat
\end{abstract}

\section{INTRODUTION}

Wheat is counted among the 'big three' cereal crops, with over 600 million tones being harvested annually. For example, in 2007, the total world harvest was about 607 million tones compared with 652 million tones of rice and $785 \mathrm{~m}$ tones of maize (http://faostat.fao.org/). In Egypt, wheat is considered the first strategic food crop. It has maintained its position during that time as the basic staple food in urban areas and mixed with maize in rural areas for bread making. In addition, wheat straw is an important fodder. The importance of wheat lies in its vital nutritional and industrial commodity in which proteins and carbohydrates. Its cultivated area extended to reach 3.06 million Fadden in 2006 growing season, yielded about 8.274 million ton, with an average of 2.7 ton/fed. However, that production does not meet our domestic needs. So, Egypt imports large amounts of wheat to face the great needs of the high population increment of people. Therefore, maximum yields from the whole area including those salt-affected soils needed. 
Farouk, S.

Salinity has drawn extensive attention throughout the world because over $6 \%$ of the earth's land area (800 million hectares) is affected by either salinity or the associated conditions of sodicity (FAO, 2008). Considering that more than $33 \%$ of Egyptian land is salt affected soil due to poor soil and water management in the irrigated areas, the salinity problem became of great importance for agriculture production in Egypt. The deleterious effects of salinity may be due to osmotic and ionic effects as well as oxidative stress (Munns, 2002). Salinity induces generation of reactive oxygen species (ROS) such as singlet oxygen, superoxide anion, hydroxyl radicals and concomitantly $\mathrm{H}_{2} \mathrm{O}_{2}$ (Hernandez et al., 1995, Farouk, 2009a). The free radicals disrupt normal metabolism through peroxidation of lipids, denaturating proteins and nucleic acids (Bor et al., 2003).

Numerous reports are available where attempts have been made to reduce oxidative stress in plants by exogenous foliar application of ascorbic acid and a-tocopherol (Oertli, 1987; Farouk, 2009a). Ascorbic acid (AsA) is one of the most important antioxidants abundantly occurring in plant as well as required in trace amount to maintain normal growth in higher plants (Smirnoff 2000). The ability of ascorbate to loose or donate electrons to produce MDHA is the basis of its biologically useful antioxidant capacity (Buettner and Schafer, 2004). Despite its role in scavenging ROS, AsA is also involved in regulating photosynthetic capacity by controlling stomatal movement (Chen and Gallie, 2004). AsA influences mitosis and cell growth in plants (Noctor and Foyer, 1998; Smirnoff and Wheeler, 2000), affects phytohormone-mediated signaling processes during the transition from the vegetative to the reproductive phase as well as the final stage of development and senescence (Barth et al., 2006; Farouk 2009a). Foliar application of ascorbic acid to different plant species was found to have simulative effect on the growth, dry matter accumulation and yield (Arisha 2000; Abd EL-Aziz et al, 2007; Beltagi, 2008). In this concern, Amin et al., (2008) on wheat plants indicate that there was a progressive increase in shoot length, number of tillers and spikes, flag leaf area, blades area/plant, spike length, grain index (g), grain and straw yield per plant and per fed by increasing ascorbic acid level up to $400 \mathrm{mg} \mathrm{L}^{-1}$. They are added that photosynthetic pigments in the leaves as well as some biochemical constituents in grains were significantly increased by increasing concentration of ascorbic acid.

$\alpha$-Tocopherols are exclusively located in the plastid or thylakoid membrane, and their biosynthesis has been observed only in plants. Tocopherole protect chloroplast membranes from photoxidation and help to provide an optimal environment for the photosynthetic machinery. Most of proposed $\alpha$-tocopherole functions are related to their antioxidant properties, the most prominent of which is protection of polyunsaturated fatty acids from lipids peroxidation by quenching and scavenging various ROS. Tocopherole and its role in amelioration of plants against stresses were studied by many authors (EL-Bassiouny et al., 2005; EL-Tohamy and El-Gready, 2007; Hussein et al., 2007).

In spite of these controversies, antioxidants can play an important role in the development of salt tolerance in crops. Therefore, the main 
objective of the present study was to study the possibility of using ascorbic acid or a-tocopherol on alleviating the harmful effect of salinity on growth characters and root anatomy as well as yield and its components of wheat plant.

\section{MATERIALS AND METHODS}

Fifteen uniform wheat grains (Giza 168 cultivar) per pot were sown on $1^{\text {st }}$ December and $15^{\text {th }}$ of November in the first and second season (2006/2007 and 2007/2008) respectively. Closed bottom plastic pots $(30 \mathrm{~cm}$ in diameter) containing $15 \mathrm{~kg}$ clayey soil with or without $\mathrm{NaCl}$ were used. The chemical analyses of the soil used are presented in Table (1).

Table (1).Chemical analysis of the soil used

\begin{tabular}{|c|c|c|c|c|c|c|c|}
\hline \multicolumn{4}{|c|}{ Anions meq/100 g soil } & \multicolumn{4}{c|}{ Cations meq/100 g soil } \\
\hline $\mathrm{Cl}^{-}$ & $\mathbf{S O}_{4}{ }^{-}$ & $\mathbf{C O}_{3}{ }^{2}$ & $\mathbf{H C O}_{3}{ }^{-}$ & $\mathbf{N a}^{+}$ & $\mathbf{K}^{+}$ & $\mathbf{C a}^{2+}$ & $\mathbf{M g}^{2+}$ \\
\hline 0.51 & 0.786 & - & 0.27 & 0.45 & 0.006 & 0.38 & 0.60 \\
\hline
\end{tabular}

A factorial experiment was design and conducted in the base of completely randomized design $(R C D)$ with six replications for each treatment. Salinization was performed by adding $\mathrm{NaCl}$ solution to adjust the salt concentration in the soil at different levels viz $0.8,7.5$ and $11.5 \mathrm{dsm}^{-1}$ of oven dried soils. Two weeks after sowing, the seedlings were thinned to 10 uniform seedlings per pot. Phosphorous and potassium fertilizers were added to the soil before sowing at the rate of $5 \mathrm{~g} \mathrm{P}_{2} \mathrm{O}_{5}$ in the form of calcium super phosphate $\left(15.5 \% \mathrm{P}_{2} \mathrm{O}_{5}\right)$ and $2 \mathrm{~g} \mathrm{~K}_{2} \mathrm{O}$ in the form of potassium sulphate (48\%). Ammonium nitrate (33.5\%) was added at the rate of $4 \mathrm{~g} \mathrm{~N} /$ pot in two equal portions; the first during the seedling stage and the second at the appearance of flag leaf. At 40 days from sowing (DFS), the pots of each salinity levels divided into three groups. Plants of the first group was used as control and sprayed with distilled, while the other groups were sprayed twice (i.e after 40 and 50 DFS) with aqueous solutions of either ascorbic or atocopherol at the rate of $100 \mathrm{mg} / \mathrm{l}$ till dripping after adding tween 20 as a wetting agent. At heading (65 DFS), four randomly selected plants were harvest per pot for determination growth characteristics i.e., shoot length $(\mathrm{cm})$, number of tillers per plant, leaf number per plant, and shoot dry weight (g) as well as membrane stability index, nitrogen and phosphorous content. At harvest stage (150 DFS) spike length, number of spiklet per spike, grain number per spike, grain weight per spike, 100 grain weight was recorded. Moreover, grain quality was recorded as the percentage of carbohydrates, protein, phosphorus and potassium.

Membrane stability Index (MSI) was assayed by estimating the ions leaching from leaf tissue into distilled water (Sairam et al., 1997). Plant material $(0.1 \mathrm{~g})$ was taken in $10 \mathrm{ml}$ of distilled water in two sets. One set was subjected to $40{ }^{\circ} \mathrm{C}$ temperature for $30 \mathrm{~min}$ and its conductivity was reported using a conductivity meter $\left(\mathrm{C}_{1}\right)$. Second set was kept in a boiling water bath for $10 \mathrm{~min}$ and its conductivity was also recorded $\left(\mathrm{C}_{2}\right)$. MSI was calculated as 
Farouk, S.

MSI $=\left[1-\left(\mathrm{c}_{1} / \mathrm{c}_{2}\right)\right] \times 100$. Total carbohydrates were estimated using the anthrone method of Sadasivam and Manickam (1996). Protein percentage was calculated by multiplying the nitrogen percentage by 5.7. For nitrogen, potassium and phosphorus determination, dry wheat flag leaf or grains were digested with $\mathrm{HClO}_{3} / \mathrm{H}_{2} \mathrm{SO}_{4}$ until a sample has become clear cooled and made up to $50 \mathrm{ml}$ using deionized water. Total nitrogen was determined by microkjeldahl method. Potassium was determined by flame photometer (Kalra, 1998). Moreover, phosphorous using ammonium molybdate and ascorbic acid (Cooper, 1977) was determined.

Small pieces of 65 days old adventitious roots $(0.5-1 \mathrm{~cm})$ and wheat grains at harvesting were taken to the anatomical studies. The samples were fixed in formalin aceto-alcohol for $48 \mathrm{~h}$, dehydrated via n-butanole series and embedded in paraffin wax $\left(52-54{ }^{\circ} \mathrm{C}\right.$ melting points). Sections were prepared using a rotary microtome at 15-17 $\mu \mathrm{m}$ thickness, stained with Erythrosin/Crystal Violet (Johanson, 1940) and finally mounted in Canada balsam. Selected sections were examined using light microscope to determining the anatomical changes.

The data were statistically analyzed following Analysis of Variance (ANOVA) technique and mean separations were adjusted by the Multiple Comparison test (Norman and Streiner, 2003) using the statistical computer programme MSTAT-C v.1.2. Means were compared by using LSD test at $5 \%$ level of significance.

\section{RESULTS AND DISCUSSION}

\section{Growth Parameters:}

Data presented in Tables $(2,3)$ clearly show that shoot length, number of tillers per plant, leaf number per plant, and shoot dry weight of wheat plant were significantly decreased by increasing salinity level up to $11.5 \mathrm{dSm}^{-1}$. The great reduction was observed under the high salinity level.

Foliar application of ascorbic acid (AsA) or tocopherol (Toc) at 100 $\mathrm{mg} / \mathrm{l}$ promoted growth criteria of wheat plants compared to corresponding untreated plants at 65 days from sowing (DFS). AsA was the most effective treatment in increasing growth parameters than Toc.

As regard to the interactions, the data in the same tables reveale that application of AsA under low salinity level increased significantly all growth parameter, meanwhile under high salinity level, application of AsA counteracted the harmful effect of salinity on plant growth. Application of Toc under low or high salinity levels help plant to alleviate the harmful effect of salinity on plant growth. 
Table (2). Shoot length (cm), and number of tillers per plant as affected by salinity with or without antioxidants at 65 days from sowing in the two growing seasons.

\begin{tabular}{|c|c|c|c|c|c|c|c|c|}
\hline \multirow{3}{*}{ Characters } & \multirow{2}{*}{\multicolumn{8}{|c|}{$\begin{array}{l}\text { First seasom } \\
\text { Antioxidants (B) }\end{array}$}} \\
\hline & & & & & & & & \\
\hline & \multicolumn{4}{|c|}{ Shoot length (cm) } & \multicolumn{4}{|c|}{ Number of tillers per plant } \\
\hline $\begin{array}{l}\text { Salinity } \\
\left(\mathrm{dSm}^{-1}\right)(\mathrm{A})\end{array}$ & 0 & AsA & $\alpha$-Toc & Mean & 0 & AsA & $\alpha-$ Toc & Mean \\
\hline Control (0.12) & 62.9 & 76.2 & 64.6 & 67.9 & 4.00 & 5.66 & 4.66 & 4.77 \\
\hline 7.5 & 58.0 & 65.6 & 61.1 & 61.5 & 3.33 & 5.00 & 4.00 & 4.11 \\
\hline 11.5 & 43.1 & 55.5 & 51.3 & 49.9 & 2.00 & 3.00 & 2.33 & 2.44 \\
\hline Mean & 54.6 & 65.7 & 59.0 & & 3.11 & 4.55 & 3.66 & \\
\hline LSD 5\% & $\begin{array}{c}\mathrm{A} \\
1.154\end{array}$ & $\begin{array}{c}\mathrm{B} \\
1.142 \\
\end{array}$ & $\begin{array}{c}A B \\
2.00\end{array}$ & & $\begin{array}{c}A \\
0.381\end{array}$ & $\begin{array}{c}\mathrm{B} \\
0.368 \\
\end{array}$ & $\begin{array}{l}\mathrm{AB} \\
\mathrm{NS}\end{array}$ & \\
\hline \multicolumn{9}{|c|}{ Second season } \\
\hline Control (0.12) & 64.4 & 78.8 & 65.5 & 69.5 & 4.37 & 6.00 & 5.00 & 5.12 \\
\hline 7.5 & 60.0 & 67.9 & 62.3 & 63.4 & 3.66 & 5.00 & 4.00 & 4.22 \\
\hline 11.5 & 43.5 & 56.5 & 52.6 & 50.8 & 2.00 & 3.00 & 2.66 & 2.55 \\
\hline Mean & 55.9 & 67.7 & 60.1 & & 3.34 & 4.66 & 3.88 & \\
\hline LSD 5\% & $\begin{array}{c}\text { A } \\
1.79\end{array}$ & $\begin{array}{c}\mathrm{B} \\
1.792\end{array}$ & $\begin{array}{c}\mathrm{AB} \\
3.10\end{array}$ & & $\begin{array}{c}\mathrm{A} \\
0.33\end{array}$ & $\begin{array}{c}\mathrm{B} \\
0.336\end{array}$ & $\begin{array}{l}\mathrm{AB} \\
\mathrm{NS}\end{array}$ & \\
\hline
\end{tabular}

Table (3). Leaf number per plant and shoot dry weight ( $\mathrm{g} / \mathrm{plant}$ ) of wheat plant as affected by salinity with or without antioxidants at 65 days from sowing in the two growing seasons.

\begin{tabular}{|c|c|c|c|c|c|c|c|c|}
\hline \multirow{3}{*}{ Characters } & \multirow{2}{*}{\multicolumn{8}{|c|}{$\begin{array}{c}\text { First season } \\
\text { Antioxidants (B) }\end{array}$}} \\
\hline & & & & & & & & \\
\hline & \multicolumn{4}{|c|}{ Leaf number per plant } & \multicolumn{4}{|c|}{ Shoot dry weight (g) } \\
\hline $\begin{array}{c}\text { Salinity } \\
\left(\mathrm{dSm}^{-1}\right)(\mathrm{A})\end{array}$ & 0 & AsA & $\alpha$-Toc & Mean & 0 & AsA & A-Toc & Mean \\
\hline Control $(0.12)$ & 18.0 & 21.6 & 19.0 & 19.5 & 12.48 & 14.02 & 13.27 & 13.25 \\
\hline 7.5 & 16.6 & 20.0 & 17.0 & 17.8 & 11.57 & 13.39 & 12.25 & 12.40 \\
\hline 11.5 & 11.6 & 15.6 & 14.3 & 13.8 & 8.68 & 10.98 & 10.68 & 10.11 \\
\hline Mean & 15.4 & 19.0 & 16.7 & & 10.91 & 12.79 & 12.06 & \\
\hline \multirow[t]{2}{*}{ LSD $5 \%$} & $\begin{array}{c}\text { A } \\
0.538\end{array}$ & $\begin{array}{c}\mathrm{B} \\
0.553\end{array}$ & $\begin{array}{c}\mathrm{AB} \\
0.93\end{array}$ & & $\begin{array}{c}A \\
0.329\end{array}$ & $\begin{array}{c}B \\
0.352\end{array}$ & $\begin{array}{c}\mathrm{AB} \\
0.570\end{array}$ & \\
\hline & \multicolumn{8}{|c|}{ Second season } \\
\hline Control (0.12) & 19.0 & 23.3 & 20.0 & 20.7 & 12.99 & 14.85 & 13.80 & 13.88 \\
\hline 7.5 & 17.3 & 21.6 & 18.3 & 19.0 & 11.99 & 13.98 & 12.86 & 12.94 \\
\hline 11.5 & 12.3 & 17.0 & 16.0 & 15.1 & 8.77 & 11.66 & 11.06 & 10.49 \\
\hline Mean & 16.2 & 20.6 & 18.1 & & 11.25 & 13.49 & 12.57 & \\
\hline LSD 5\% & $\begin{array}{c}A \\
0.538\end{array}$ & $\begin{array}{c}B \\
0.550\end{array}$ & $\begin{array}{c}\mathrm{AB} \\
0.93\end{array}$ & & $\begin{array}{c}A \\
0.327\end{array}$ & $\begin{array}{c}B \\
0.348\end{array}$ & $\begin{array}{c}A B \\
0.567\end{array}$ & \\
\hline
\end{tabular}

In the present investigation, the responses of wheat plant to high level of salinity were reflected by decreases in shoot length, number of tillers and leaf number per plant, and shoot dry weight. The inhibitory effects of salt stress on these parameters add more support to the ubiquitous finding of earlier investigations (Cicek and Cakirlar, 2008; Athar et al., 2008; Garg and Manchanda, 2009). The deleterious effects of salinity on plant growth may be due to one or more from its effects on inhibition of photosynthesis, induction of growth inhibitor (abscisic acid) which cause premature senescence of 


\section{Farouk, S.}

leaves and reduced leaf area (Kashem et al., 2000 and Farouk 2009a), decreasing leaf protein content (Farouk, 2009a), reduction ability to produce and utilize assimilates/photosynthates, reducing the supply of assimilates to the growing regions (Kashem et al., 2000) and/or due to osmotic stress that causes water deficit and reduces water absorption. Alternatively, it can be due to specific effects of the ions that cause toxicity and nutritional imbalance caused mainly by lower absorption rates of potassium and lower utilization rates of potassium, calcium and phosphorous (Romero and Maranon, 1994). Moreover, the adverse effect of high salinity concentration on growth could be ascribed to that salinity has been shown to reduce the synthesis of DNA, RNA and protein in many plants which might lead to disturbance in metabolic activities, cell division and elongation. Each of these hypotheses has some merit and may contribute in some ways towards the long term effects of growth.

In contrast to the effect of salinity, it was found that application of both antioxidants as a foliar spray promoted the growth of wheat cultivar under normal or salinized condition. These findings can be related to some earlier studies in which it has been observed that exogenous application of antioxidants as AsA or Toc promoted plant growth (Athar et al, 2008, Beltagi 2008, Mady, 2009). In relation to enhancing effects of antioxidants on growth of wheat under normal or salinized conditions observed in the present study, it may be worth to mention that vitamins are considered as non-hormonal plant growth promoters. More importantly, it is suggested that antioxidants, as environmentally friendly and cheap compounds, could be beneficial in substituting the synthetic auxins in enhancing plant growth and productivity. Application of antioxidants have caused enhancement in growth of nonstressed and stressed plants may have been due to increase in cell division and/or cell enlargement, although these phenomena were not examined in the present study. Furthermore, there are some reports which provide evidence that AsA accelerate cell division and cell enlargement as observed in different plants (Cabo et al., 1996; Barth et al., 2006) through its action in cell vaculation as reported by Cordoba et al., (1996). Cell expansion is controlled by different processes like coordinated alterations in wall mechanical properties, biochemical processes and gene expression (Cosgrove 2000) and/or to influence DNA replication (Noctor and Foyer, 1998). These findings and the results of the present investigation suggest that growth promoting effect of AsA under non-saline or saline conditions may have been due to enhanced antioxidant capacity (Farouk, 2009a), and increase in cell division and cell enlargement which reflect to increasing the thickness of Leaves (Farouk, 2009b) and root (Table, 4). Moreover, there are some reports indicate that application of Toc promoted plant growth (ELTohamy and El-Gready 2007 and Hussein et al 2007) They attributed these effects to the fact that it is a low molecular weight lipophilic antioxidants which protect membrane from oxidative damage.

\section{Root structure:}

Table (4) and Figure (1) reveal that either AsA or Toc increased the thickness of the adventitious roots due to increase in the thickness of cortex 
and vascular cylinder as well as diameter of metaxylem vessel leading to enhancing the absorption of solutes and water from the soil, which undoubtedly reflects on growth and yield.

With regard to the effect of salinity on the adventitious roots, Table (4) and Figure (1) show that salinity levels decreased root thickness as a result of decreasing cortex tissue thickness and vascular cylinder. Metaxylem vessels diameter was also decreased. The results due to high salinity levels may be correlated with inhibition the procambial activity leading to retardation in the differentiation of the root conductive tissues. It appears clear that both antioxidants partially overcome the depression effect of high salinity level of $\mathrm{NaCl}$ on the root structure. AsA is the most effective than Toc in increasing vascular cylinder thickness.

Table (4). Root anatomical characteristics of wheat plants at 65 day from sowing as affected by salinity with or without antioxidants in the second season.

\begin{tabular}{|c|c|c|c|c|c|c|c|c|c|}
\hline \multicolumn{2}{|c|}{ Treatment } & \multicolumn{2}{|c|}{$\begin{array}{l}\text { Diameter of root } \\
\text { cross section }\end{array}$} & \multicolumn{2}{|c|}{$\begin{array}{c}\text { Diameter of } \\
\text { vascular } \\
\text { cylinder }\end{array}$} & \multicolumn{2}{|c|}{$\begin{array}{c}\text { Thickness of } \\
\text { cortex }\end{array}$} & \multicolumn{2}{|c|}{$\begin{array}{c}\text { Diameter of } \\
\text { metaxylem } \\
\text { vessel }\end{array}$} \\
\hline Salinity $\left(\mathrm{dSm}^{-1}\right)$ & $\begin{array}{c}\text { Antioxidants } \\
\mathrm{mg} / \mathrm{L}\end{array}$ & $\mu$ & $100 \%$ & $\mu$ & $100 \%$ & $\mu$ & $100 \%$ & $\mu$ & $100 \%$ \\
\hline \multirow[t]{3}{*}{ Control (0.8) } & Water & 104.56 & 100 & 35.7 & 100 & 32.36 & 100 & 9.24 & 100 \\
\hline & AsA & 122.33 & 116 & 43.33 & 121 & 37.76 & 116 & 9.89 & 107 \\
\hline & Toc & 110.83 & 105 & 38.8 & 108 & 33.16 & 102 & 9.57 & 103 \\
\hline \multirow[t]{3}{*}{7.5} & Water & 92.3 & 88 & 32.8 & 91 & 27.46 & 84 & 8.45 & 91 \\
\hline & AsA & 104.22 & 97 & 40.76 & 114 & 30.03 & 95 & 9.01 & 97 \\
\hline & Toc & 95.63 & 91 & 37.23 & 104 & 27.23 & 90 & 8.76 & 94 \\
\hline \multirow[t]{3}{*}{11.5} & Water & 77.76 & 74 & 26.22 & 73 & 22.56 & 69 & 7.34 & 79 \\
\hline & AsA & 100.56 & 96 & 46.66 & 130 & 24.96 & 83 & 8.14 & 88 \\
\hline & Toc & 92.12 & 88 & 43.86 & 122 & 22.13 & 74 & 7.87 & 85 \\
\hline
\end{tabular}

Nitrogen and phosphorous content as well as Membrane stability Index:

Data presented in Table (5) show that increasing salinity levels up to $11.5 \mathrm{dSm}^{-1}$ decreased significantly nitrogen and phosphorus content and MSI\% in wheat flag leaf in both season. The great reduction occurred under high salinity levels. On the other hand, nitrogen, phosphorus content and $\mathrm{MSI} \%$ in flag leaf was considerably increased due to foliar application of either AsA or Toc at $100 \mathrm{mg} / \mathrm{l}$ against control plants. AsA was the most effective than Toc in increasing the content of nitrogen and phosphorous as well as MSI\%.

It has been observed that any of antioxidants used combined with salinity levels caused a significant decreasing effect in nitrogen and phosphorus content and MSI\% as compared with untreated plants under corresponding salinity levels. Usually either of AsA or Toc partially counteracted the harmful effect of salinity especially at high level on nitrogen and phosphorous content. 


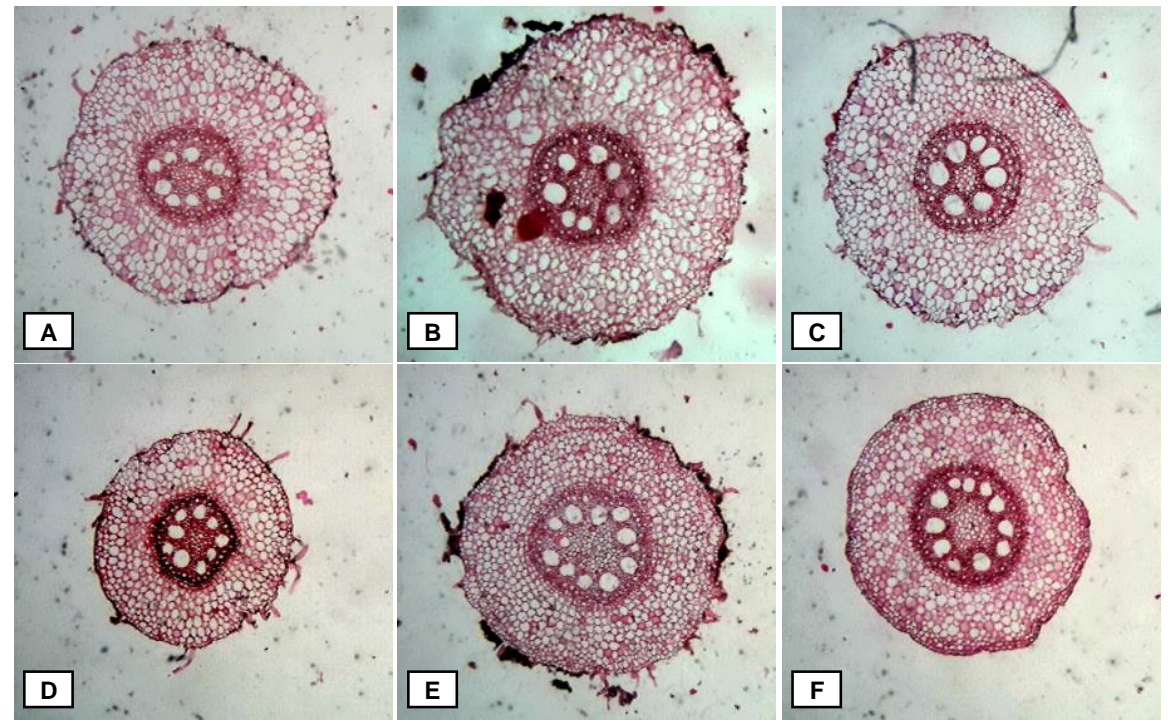

Figure 1. Anatomical characteristics of wheat root as affected by salinity with or without antioxidants at 65 days from sowing in the second season (A: control; B: AsA; C: Toc; D: high salinity level "S"; E: S+AsA; F: S+Toc), 40X

The results show also that, increasing salinity level decreased significantly MSI as compared with unsalinized plants. In this concern, Azooz (2004) indicate that MSI deceased significantly with $\mathrm{NaCl}$ up to $200 \mathrm{mM}$. On the other hand, MSI was considerably increased as results of foliar application of antioxidants. This increase in MSI might be related to induction of antioxidant responses that protect the plant from oxidative damage, which also coincided with a decrease in the level of $\mathrm{H}_{2} \mathrm{O}_{2}$ and MDA (Farouk, 2009a)

Salt stress is generally recognized as injurious to plants by disturbing the electrolyte balance, resulting in the deficiency of some nutrients and the excess of certain unwanted salts (Farouk, 2009a,b). In this connection Farouk (2009b) pointed out that salinization impaired $\mathrm{N}$ accumulation and incorporation into protein and raised total free amino acid accumulation in salinized plants. Moreover, An increase in chloride uptake and accumulation is accompanied by a decrease in shoot nitrate concentrations of plants due to the competition between chloride and nitrate which decreases nitrate content (Khan and Srivastava,1998). This increment in N concentration due to AsA treatments could be explained by the fining of Talaat (2003) who showed that the accumulation of nitrate by AsA foliar application might may be due to the positive effect of AsA on root growth which consequently increased nitrate absorption. This result was confirmed with the present investigation where application of either antioxidant increased significantly the thickness of root and the thickness of metaxylem vessels and vascular cylinder (Table, 4).

In the present study, the decline in $\mathrm{P}$ concentration at high salinity levels may have occurred due to the inhibition in $\mathrm{P}$ transport and its uptake (Garg and Manchanda, 2009). 
J. Plant Production, Mansoura University, Vol. 1(8), August, 2010 5-6 


\section{Farouk, S.}

This reduction may be also due to precipitate phosphorous ions with calcium in salt stressed soil and become unavailable to plants. In other cases, reduction in plant phosphorous content may result from reduced activity of phosphorous in the soil solution due to the high ionic strength of the media (Awad et.al., 1990). Furthermore, the reduction in $\mathrm{P}$ uptake under saline condition could be explained on the fact that $\mathrm{Na}$ salt raised the $\mathrm{pH}$ of the soil, which in turn reduced the availability of $P$ to the plants. On the other hands, Application of Ascorbic acid increased significantly phosphorus contents in many plants (Abd EL-Aziz et al., 2007).

\section{Yield and its components:}

Although salinity affects negatively on all stages of wheat growth and its development, grain yield is much more depressed by salt than is vegetative growth. Data presented in Tables $(6,7)$ show that yield and its components represented as spike length, number of spiklets per spike, gain number per spike, gain weight per spike and 100 grain weight were significantly decreased with increasing salinity levels up to $11.5 \mathrm{dSm}^{-1}$.

On the other hand, foliar application of both antioxidants resulted in the highest increase in yield and its components. As regard to the interactions the data in the same tables proved that application of ascorbic acid under high salinity level and tocopherol under low or high salinity levels counteracted the harmful effect of salinity on yield and its component. On contrast application of ascorbic acid under low salinity levels increased significantly wheat yield and its components as compared with control plant.

Table (7). Grain weight per spike (g) and 100 grain weight (g) of wheat plant as affected by salinity with or without antioxidants in the two growing seasons

\begin{tabular}{|c|c|c|c|c|c|c|c|c|}
\hline \multirow{3}{*}{ Characters } & \multicolumn{8}{|c|}{ First season } \\
\hline & \multicolumn{8}{|c|}{ Antioxidants (B) } \\
\hline & \multicolumn{4}{|c|}{ Grain weight per spike (g) } & \multicolumn{4}{|c|}{100 grain weight $(\mathrm{g})$} \\
\hline Salinity $\left(\mathrm{dSm}^{-1}\right)(\mathrm{A})$ & 0 & AsA & $\alpha-T o c$ & Mean & 0 & AsA & $\alpha-$ Toc & Mean \\
\hline Control (0.12) & 2.77 & 4.06 & 3.14 & 3.32 & 4.08 & 4.82 & 4.26 & 4.38 \\
\hline 7.5 & 2.50 & 3.84 & 2.63 & 2.99 & 3.74 & 4.40 & 3.93 & 4.02 \\
\hline 11.5 & 1.69 & 2.32 & 2.16 & 2.05 & 2.07 & 3.60 & 2.69 & 2.78 \\
\hline Mean & 2.32 & 3.40 & 2.64 & & 3.29 & 4.27 & 3.62 & \\
\hline LSD 5\% & $\begin{array}{c}A \\
0.15\end{array}$ & $\begin{array}{c}B \\
0.14\end{array}$ & $\begin{array}{c}A B \\
0.27\end{array}$ & & $\begin{array}{c}A \\
0.17\end{array}$ & $\begin{array}{c}B \\
0.16\end{array}$ & $\begin{array}{c}A B \\
0.30\end{array}$ & \\
\hline & \multicolumn{8}{|c|}{ Second season } \\
\hline Control (0.12) & 3.59 & 4.27 & 3.98 & 3.94 & 4.23 & 5.47 & 4.37 & 4.69 \\
\hline 7.5 & 2.63 & 4.08 & 2.84 & 3.18 & 3.91 & 4.67 & 4.05 & 4.21 \\
\hline 11.5 & 1.79 & 2.51 & 2.36 & 2.22 & 2.07 & 3.71 & 3.25 & 3.01 \\
\hline Mean & 2.67 & 3.62 & 3.06 & & 3.40 & 4.61 & 3.89 & \\
\hline LSD 5\% & $\begin{array}{c}A \\
0.14\end{array}$ & $\begin{array}{c}B \\
0.14\end{array}$ & $\begin{array}{c}\mathrm{AB} \\
0.25\end{array}$ & & $\begin{array}{c}A \\
0.17\end{array}$ & $\begin{array}{c}B \\
0.15\end{array}$ & $\begin{array}{c}\mathrm{AB} \\
0.30\end{array}$ & \\
\hline
\end{tabular}

Soil salinity seriously affects the yield of wheat like other field crops. Yield reduction may range from a slight loss to complete crop failure depending upon the severity of salinity problem and tolerance limit of crop. The magnitude of salt induced yield loss could not be attributed to single 
factor. Different physiological and biochemical factors at different stage of wheat plant may be involved. One factor may be the over all control mechanisms (before flowering) of sodium uptake through root properties and its subsequent distribution in different vegetative and floral parts especially in flag leaves where it cause leaf senescence (Farouk, 2009a) and mortality thereby reduces transportation of total assimilate to the growing regions (Munns, 2002). Which may be reduced the number of fertile spikes and spike bearing tillers (Steppuhu and Wall, 1997). It may be concluded that the reduction in fertile tiller, leaf area as well as decreasing photosynthetic pigments resulting in reduction in the supply of carbon assimilate and photosynthetic rate which lead to slow translocation of photoassimilates towards the developing grains (He and Crammer, 1993).

The inhibitory effects of salt on fertility may be due to differential competition in carbohydrates supply between vegetative growth and constrained its distribution to the developing spike (Murty and Murty, 1982), whereas other is probably linked to reduce viability of pollen grains or in the receptivity of the stigmatic surface or both as well as decreasing in the number of fertile florets under stress conditions, thus resulting failure of seed set (Abdullah et al., 2001). In this connection, Saini and Westgate (2000) indicate that decreasing water potential resulted from increasing salinity stress specially during microosporogenesis caused a significant increase in pollen sterility due to increasing ABA concentration. Sheoran and Saini (1996) reported decreases in invertase activity and starch accumulation in the developing pollen of wheat and rice when water potential is low. These investigation ascribed pollen sterility to losses in invertase activity that resulted in an inability of the pollen to metabolize incoming sucrose to hexose. Such conditions may result in preventing pollen tube development carrying the two male gametes and therefore preventing fertilization and seed development. The reduction in pollen viability has been related to decreased calcium mobilization from plant leaves treated with sodium chloride (Cresti et.al., 1994) which is important in pollen germination and pollen tube growth. In addition this reduction in yield may be due to a decreasing in vascular bundles dimensions (Table, 4) resulted in a lower accumulation of water necessary for photosynthesis, which lead to slow translocation of photoassimilate towards the developing seed.

On contrast, the increases in wheat yield and its components obtained in this study due to spraying with either AsA or Toc could be a result of their responding increases in leaves content of photosynthetic pigments (Farouk, 2009a), enhanced photosynthetic rate under non saline or saline conditions due to increase stomatal conductance coupled with an increase in sub-stomatal $\mathrm{CO}_{2}$ (Athar et al., 2008) and growth parameters which may be reflected as improvements in plant fruiting performance and yield. Similarly, Abdel- Hameed (2004) and Athar et al. (2008) on wheat found that spraying ascorbic had favorable effects on growth characters and yield particularly with the higher concentration. Moreover EL-Bassiouny et al. (2005) indicate that application of Toc or AsA increased significantly seed yield per plant, and 100 seed weight. 
Farouk, S.

Grain quality:

Data in Tables $(8,9)$ indicate that salinity at both concentrations markedly decreased grain quality as represented by the percentage of carbohydrate, protein, $\mathrm{P}$, and $\mathrm{K} \%$ in grains.

Table (8). Carbohydrates and protein percentages of wheat grains as affected by salinity with or without antioxidants in the two growing seasons

\begin{tabular}{|c|c|c|c|c|c|c|c|c|}
\hline \multirow{3}{*}{ Characters } & \multicolumn{8}{|c|}{ First season } \\
\hline & \multicolumn{8}{|c|}{ Antioxidants (B) } \\
\hline & \multicolumn{4}{|c|}{ Carbohydrates percentage } & \multicolumn{4}{|c|}{ Protein percentage } \\
\hline $\begin{array}{c}\text { Salinity } \\
\left(\mathrm{dSm}^{-1}\right)(\mathrm{A})\end{array}$ & 0 & AsA & $\alpha-$ Toc & Mean & 0 & AsA & $\alpha-$ Toc & Mean \\
\hline Control $(0.12)$ & 70.4 & 72.7 & 71.1 & 71.4 & 12.2 & 13.0 & 12.3 & 12.5 \\
\hline 7.5 & 69.2 & 71.7 & 69.9 & 70.2 & 11.6 & 12.6 & 12.2 & 12.1 \\
\hline 11.5 & 64.6 & 68.2 & 67.6 & 66.8 & 9.58 & 11.4 & 11.2 & 10.7 \\
\hline Mean & 68.0 & 70.8 & 69.5 & & 11.1 & 12.3 & 11.9 & \\
\hline \multirow[t]{2}{*}{ LSD 5\% } & $\begin{array}{c}A \\
0.336\end{array}$ & $\begin{array}{c}\mathrm{B} \\
0.345\end{array}$ & $\begin{array}{c}\mathrm{AB} \\
0.583\end{array}$ & & $\begin{array}{c}A \\
0.199\end{array}$ & $\begin{array}{c}\mathrm{B} \\
0.185\end{array}$ & $\begin{array}{c}\mathrm{AB} \\
0.346\end{array}$ & \\
\hline & \multicolumn{8}{|c|}{ Second season } \\
\hline Control $(0.12)$ & 71.2 & 73.4 & 71.8 & 72.1 & 12.3 & 13.3 & 12.5 & 12.7 \\
\hline 7.5 & 70.1 & 72.2 & 70.5 & 70.9 & 12.9 & 12.8 & 13.2 & 12.9 \\
\hline 11.5 & 64.7 & 69.6 & 68.6 & 67.6 & 9.89 & 11.6 & 11.3 & 10.9 \\
\hline Mean & 68.6 & 71.7 & 70.3 & & 11.6 & 12.5 & 12.3 & \\
\hline LSD 5\% & $\begin{array}{c}A \\
0.535\end{array}$ & $\begin{array}{c}B \\
0.373\end{array}$ & $\begin{array}{c}\mathrm{AB} \\
0.927\end{array}$ & & $\begin{array}{c}A \\
0.130\end{array}$ & $\begin{array}{c}B \\
0.124\end{array}$ & $\begin{array}{c}A B \\
0.225\end{array}$ & \\
\hline
\end{tabular}

Table (9). Phosphorous and potassium percentages of wheat grains as affected by salinity with or without antioxidants in the two growing seasons

\begin{tabular}{|c|c|c|c|c|c|c|c|c|}
\hline \multirow[t]{2}{*}{ Characters } & \multicolumn{8}{|c|}{$\begin{array}{c}\text { First season } \\
\text { Antioxidants (B) }\end{array}$} \\
\hline & \multicolumn{4}{|c|}{ Phosphorous percentage } & \multicolumn{4}{|c|}{ Potassium percentage } \\
\hline $\begin{array}{c}\text { Salinity } \\
\left(\mathrm{dSm^{-1 }}\right)(\mathrm{A})\end{array}$ & 0 & AsA & $\alpha-$ Toc & Mean & 0 & AsA & $\alpha-$ Toc & Mean \\
\hline Control $(0.12)$ & 0.284 & 0.314 & 0.289 & 0.295 & 1.343 & 1.413 & 1.360 & 1.372 \\
\hline 7.5 & 0.261 & 0.298 & 0.276 & 0.278 & 1.297 & 1.380 & 1.303 & 1.326 \\
\hline 11.5 & 0.234 & 0.251 & 0.244 & 0.243 & 1.190 & 1.280 & 1.263 & 1.244 \\
\hline Mean & 0.259 & 0.287 & 0.269 & & 1.276 & 1.357 & 1.308 & \\
\hline \multirow[t]{2}{*}{ LSD 5\% } & $\begin{array}{c}A \\
0.004\end{array}$ & $\begin{array}{c}\mathrm{B} \\
0.005\end{array}$ & $\begin{array}{c}A B \\
0.007\end{array}$ & & $\begin{array}{c}A \\
0.009\end{array}$ & $\begin{array}{c}B \\
0.01\end{array}$ & $\begin{array}{c}A B \\
0.016\end{array}$ & \\
\hline & \multicolumn{8}{|c|}{ Second season } \\
\hline Control (0.12) & 0.288 & 0.331 & 0.297 & 0.305 & 1.357 & 1.450 & 1.380 & 1.395 \\
\hline 7.5 & 0.270 & 0.311 & 0.283 & 0.288 & 1.313 & 1.410 & 1.340 & 1.354 \\
\hline 11.5 & 0.235 & 0.258 & 0.250 & 0.247 & 1.193 & 1.290 & 1.280 & 1.254 \\
\hline Mean & 0.264 & 0.300 & 0.276 & & 1.287 & 1.383 & 1.333 & \\
\hline LSD 5\% & $\begin{array}{c}A \\
0.004\end{array}$ & $\begin{array}{c}\mathrm{B} \\
0.004\end{array}$ & $\begin{array}{c}A B \\
0.007\end{array}$ & & $\begin{array}{c}A \\
0.012\end{array}$ & $\begin{array}{c}B \\
0.013\end{array}$ & $\begin{array}{c}A B \\
0.022\end{array}$ & \\
\hline
\end{tabular}

The data in same tables show that foliar application of antioxidants, in particular, AsA, significantly increased the total carbohydrate percentage in wheat grains and accompanied by similar effects on protein, phosphorus and potassium percentage relative to untreated controls. The maximum values of 
total carbohydrates, protein, $\mathrm{P}$ and $\mathrm{k}$ percentages of wheat grains were obtained by ascorbic acid. Application of Ascorbic acid or Toc under all salinity levels increased the grain quality as compared to untreated plant under corresponding salinity levels. This results were confirmed with our observation in Figure (2) which indicate that application of either antioxidants increased the thickness of alerone layer in the grain as well as increased carbohydrate content (starch grain) as indicate in the figure where the endosperm is very dense than control or high salinity level.
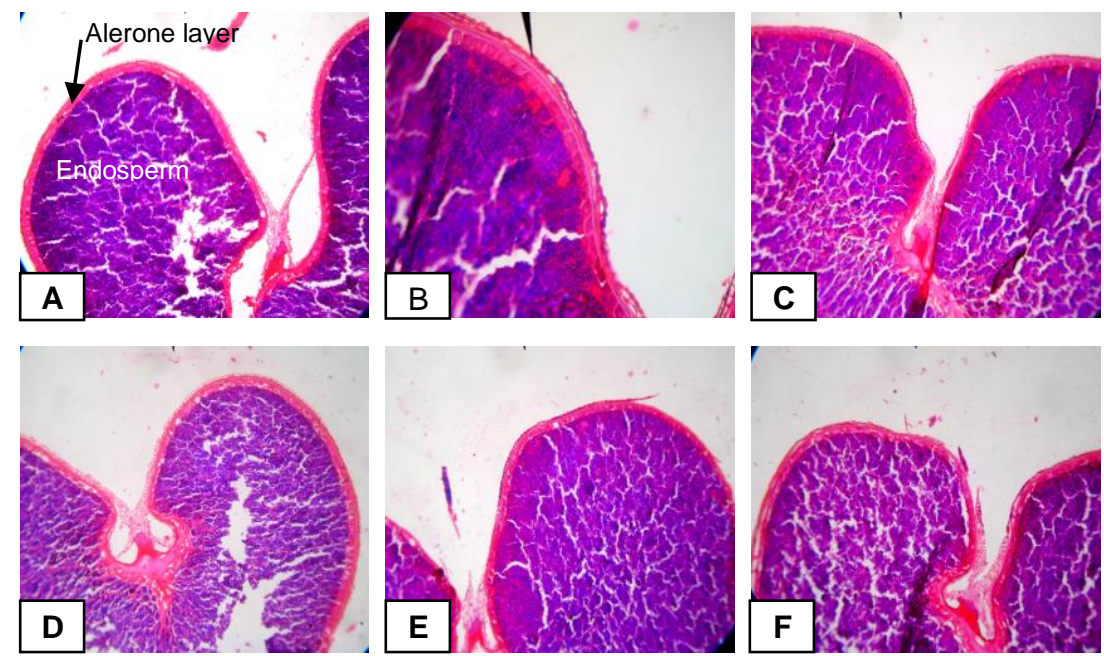

Figure 2. Anatomical characteristics of wheat grains as affected by salinity with or without antioxidants in the second season (A: control; B: AsA; C: Toc; D: high salinity level "S"; E: S+AsA; F: S+Toc), 40X

Concerning the quality of grains, the present investigation indicates that salinity stress decreased the quality of grains represented as carbohydrates, proteins, $\mathrm{P}$ and $\mathrm{K}$ percentage. The depression effect of salinity on protein content may be due to a reduction of protein synthesis or an acceleration of their degradation and/or an inhibition of amino acid incorporation into proteins (Poljakoff-Mayber 1982). Moreover, the reduction effect of salinity on carbohydrate accumulation may be attributed to reduction of photosynthetic area (Farouk, 2009), probably due to an inhibition of leaf expansion, photosynthetic pigments formation, soluble proteins in the leaves (Farouk, 2009a) and ovary; this change might cause the decline in leaves/ovary photosynthesis leading to poor sugar accumulation in the ovary (Sultana et al., 1999). Moreover, the reduction in carbohydrates accumulations in wheat grains could be related not only to an inhibition of carbohydrates translocation and photoassimilates inhibition as well as reducing carbohydrates exchange rate (Asch et al., 2000) but also due to damage in chloroplasts, accelerating chlorophyll degradation and inactive of RuBP carboxylase by oxidation damage (Rahman et al., 2002). On the other hand, application of both antioxidants improved significantly grain qualinity. In 
this concern, ascorbic acid significantly increased $\mathrm{N}, \mathrm{P}$ and $\mathrm{K}$ content sunflower seeds (El-Gabas, 2006) compared with their controls. Moreover, Application of Toc promoted wheat growth and these effects agreed with the finding of ELBassiouny et al (2005) and EL-Tohamy and El-Gready (2007) improving seed quality.

It can be concluded that foliar application of wheat cultivar Giza 168, plants with either AsA or Toc at $100 \mathrm{mg} \mathrm{l}^{-1}$, stimulate wheat growth and improved its yield represented by grain yield/plant grains index as well as carbohydrate and macroelement content of the grains.

\section{Acknowledgements}

I would like to thanks all staff member of Agric. Botany Department, Fac. of Agriculture, Mansoura University, in particular, Prof D. M. A. Khafagy for helpful insights and critical reviews of the manuscript and Prof. Dr. R.A. Fouda for his advice in anatomical study.

\section{REFERENCES}

Abd EL-Aziz, Nahed G., E.M. EL-Quesni Fatma and M.M. Farahat (2007). Response of vegetative growth and some chemical constituents of Syngonium podophyllum $\mathrm{L}$. to foliar application of thiamin, ascorbic acid and kinetin at Nubaria. World J. Agric. Sci., 3(3):301-305.

Abdel-Hameed, A.M., S.H. Sarhan and H.Z. Abdel-Salam, (2004). Evaluation of some organic acid as foliar application on growth, yield and some nutrient contents of wheat. J. Agric. Sci. Mansoura Univ., 20(5): 24762481.

Abdullah Z, M.A. Khan and T.J. Flowers (2001). causes of salinity in seed set in rice under salinity stress. J. Agron. Crop Sci., 187(1):25.

Amin A.A, A.A. Rashad and Fatma A.E. Gharib (2008) Changes in morphological, physiological and reproductive characters of wheat plants as affected by foliar application with salicylic acid and ascorbic acid. Aust. J. Bascic and Applied Sciences, 2 (2): 252-261.

Arisha H.M. (2000). Effect of vitamin C on growth, yield and tuber quality of some potato cultivars under sandy soil condition. Zagazig J. Agric. Res., 27:91-104.

Asch F., D. Dingkuhn and K. Dorffing (2000). Salinity increases Co2 assimilation but reduces growth in field grown irrigated rice. Plant Soil, 218:1-10.

Athar H.B., A. Khan and M. Ashraf (2008). Exogenously applied ascorbic acid alleviates sal-induced oxidative stress in wheat. Environmental and Expermintal Botany, 63:224-231.

Awad, A.S., D.G. Edwards and L.C. Campbell (1990): Phosphorous enhancement of salt tolerance of tomato. Crop Sci., 30:123-128.

Azooz M.M. (2004). Proteins, sugars and ion leakage as a selection criterion for the salt tolerance of three sorghum cultivars at seedling stage grow under $\mathrm{NaCl}$ and nicotinamide. Int. J. Agri. Biol., 6(1): 27-35. ISSN: 1560-8530.

Barth C.M., De Tullio and P.L. Conklin (2006). The role of ascorbic acid in the control of flowering time and the onset of senescence. J. Exp. Bot., 57:1657-1665. 
Beltagi M.S. (2008). Exogenous ascorbic acid (vitamin C) induced anabolic changes for salt tolerance in chickpea (Cicer arietinum L.) plants. African J. Plant Science, 2(10): 118-123.

Bor M., F. Ozdemir and I. Turkan (2003). The effect of salt stress on lipid peroxidation and antioxidants in leaves of sugar beet Beta vulgaris $L$. and wild Beta maritime L. Plant Sci., 164: 77-84.

Buettner G.R. and F.Q. Schafer (2004). Ascorbate as an antioxidant in vitamin c: in Asard H., May J.M., Smirnoff N. (Eds). Functions and biochemistry in Animals and Plants. Bios Scientific Publishers, Oxford, pp 173-188.

Cabo R.C., J.A. Gonza-Lez-Reyes, F. Cordoba and P. Navas. (1996). Rooting hastened in onion by ascorbate and ascorbate free radical. J. Plant Growth Regul., 15:53-56.

Chen Z. and D.R. Gallie (2004). The ascorbic acid redox state controls guard cell signaling and stomatal movement. Plant Cell, 16:1143-1162.

Cicek N. and H. Cakirlar (2008). Effects of salt stress on some physiological and photosynthetic parameters at three different temperatures in six soya bean (Glycine max L. Merr.) cultivars. J. Agron. Crop Sci., 194:3446.

Cooper T.G. (1977). The tools of biochemistry.A Wiley-Interscience Pub. John Wiley and Sons, New York.

Cordoba-Pedregosa M.C., J.A. Gonzalea-Reyes, M.S. Sandillas, P. Navas and F. Cordoba (1996). Role of apoplastic and cell wall peroxidases on the stimulation of root elongation by ascorbate. Plant Physiology, 112:1119-1125.

cosgrove D.J. (2000). Expansive growth of plant cell walls. Plant Physiology and Biochemistry, 38:109-124.

Cresti M., F. Ciampolini, M. Tattini and A. Cimato (1994). Effect of salinity on productivity and oil quality of olive (Olea europaea L.) plants. Adv. Hort. Sci., 8:211-214.

El-Bassiouny Hala, M.S., M.E. Gobarah and A.A. Ramadan (2005). Effect of antioxidants on growth, yield and favism causative agents in seeds of Vicia faba L. plants grown under reclaimed sandy soil. J. of Agron., 4(4): 281-287.

EL-Gabas N.M.M. (2006). Physiological studies on the effect of ascorbic acid and micronutients on sunflower plants grown under salinity stress M.Sc thesis Fac. Sci., AL-Azhar Univ. Egypt.

El-Tohamy W.A. and N.H.M. EL-Greadly (2007). Physiological responses, growth, yield and quality of snap beans in response to foliar application of yeast, vitamin $E$ and zinc under sandy soil conditions. Aust. J. of Bascic and Applied Sciences, 1(3):294-299.

FAO (2008) Food and Agriculture Organization statistical data.

Farouk S. (2009a). The role of ascorbic acid and $\alpha$-tocopherol in minimize of salt-induced flag leaf senescence. J. Agric. Sci. Mansoura Univ., 34 (11): $10645-10661$.

Farouk S. (2009b). The role of antioxidants in inducing wheat flag leaf osmotic adjustment under salinity stress. J. Agric. Sci. Mansoura Univ., 34 (11): 10663 - 10685.

Garg N. and G. Manchanda (2009). Role of Arabuscular Mycorrhizae in the alleviation of ionic, osmotic and oxidative stresses induced by salinity in Cajanus cajan (L.) Millsp. (pigeonpea). J. Agron. Crop Sci., 195:110123. 
Farouk, S.

He T. and G.R. Cramer (1993). Growth and ion accumulation of two rapid cycling Brassica species differing in salt tolerance. Plant Soil, 153:1931.

Hernandez J.A., E. Olmos, F.J. Corpas, F. Sevilla and L.A. DelRio (1995). Salt-induced oxidative stress in chloroplasts of pea plants. Plant Sci., 105:151-167.

Hussein M.M., L.K. Balbaa and M.S. Gaballah (2007). developing a salt tolerant cowpea using alpha tocopherol. J. Applied Sci. Research, $3(10): 1234-1239$.

Johanson D.A. (1940). Plant Microtechnique. McGraw-Hill. Inc New York and London

Kalra Y.P. (1998). Handbook of reference method for plant analysis. CRC Press, Washington, DC. ISBn 1-57444-124-8.

Kashem M.A., N. Sultana, T. Ikeda, H. Hori, T. Loboda and T. Mitsui (2000). Alteration of starch-sucrose transition in germinating wheat seed under sodium chloride salinity. J. Plant Biol., 43:121-127.

Khan M.G. and H.S. Srivastava (1998): Changes in growth and nitrogen assimilation in maize plants induced by $\mathrm{NaCl}$ and growth regulators. Biol. Plant., 41:93-99.

Mady M.A. (2009). Effect of foliar application with salicylic acid and Vitamin E on growth and productivity of tomato (Lycopersicon esculentum, Mill.) plant. J. Agric. Sci. Mansoura Univ., 34(6):6715-6726.

Munns R. (2002). Comparative physiology of salt and water stress. Plant Cell Envir., 25:239-250.

Murty P.S.S. and K.S. Murty (1982). Spikelet sterility in relation to nitrogen and carbohydrate contents in rice. Indian J. Plant Physiol., 25:40-48.

Noctor G. and C.H. Foyer. (1998). Ascorbate and glutathione: keeping active oxygen under control. Annu. Rev. Plant Physiol. Plant Mol. Biol., 49:249-279

Norman G.R. and D.L. Streiner (2003). PDQ Statistics, 3rd Ed. BC Deckker Inc, London. ISBN 1-55009-2073.

Oertli J.J. (1987). Exogenous application of vitamins as regulators for growth and development of plants, a review. Z. Pflanzenemahr Bodenk., 150: 375-391.

Poljakoff-Mayber A. (1982). biochemical and physiological responses of higher plants to salinity stress. In Biosaline Research. A Look to the future (A. San Prieto, ed.)., pp 245-270.

Rahman M.S., H. Miyake and Y. Takeoka (2002). Effects of exogenous glycinebetaine on growth and ultrastructure of salt-stressed rice seedlings (Oryza sativa L.). Plant Production Sci. , 5:33-44.

Romero J.M. and T. Marañón (1994). Long-term responses of Melilotus segetalis to salinity. i. Growth and partitioning. Plant Cell Env., 17:1243-1248.

Sadasivam S. and A. Manickam (1996): Biochemical Methods, Second eddition, New age international. India.

Saini H.S. and M.E. Westgate (2000): Reproductive development in grain crops during drought. Advances in Agron., 68:59-96.

Sairam R.K., P.S. Deshmukh and D.S. Shukla (1997). Tolerance to dought and temperature stress in relation to increased antioxidant enzyme activity in wheat. J. Agro. Crop Sci., 178:171-177. 
Sheoran I.S. and H.S. Saini (1996): Drought-induced sterility in rice: changes in carbohydrate levels and enzyme activities associated with the inhibition of starch accumulation in pollen. Sexual plant Reproduction, 9:1661-1669.

Smirnoff N. (2000). ascorbate biosynthesis and function in photo protection. Biol. Sci., 355:1455-1465.

Smirnoff N. and G.L. Wheeler (2000). Ascorbic acid in plants: biosynthesis and function. Crit. Rev. Plant Sci., 19:267-290.

Steppuhn H. and K.G. Wall (1997). Grain yield from spring sown Canadian wheat grass grown in saline rooting media. Can. J. Plant Sci.,77:63-68.

Sultana N., T. Ikeda and R. Itoh (1999). Effect of NACl salinity on photosynthesis and dry matter accumulation in developing rice grains. Environ. Exp. Bot., 42:211-220.

Talaat N.B. (2003). Physiological studies on the effect of salinity, ascorbic acid and putrescine of sweet pepper plant. Ph. D thesis, Fac. Agric., Cairo Univ.

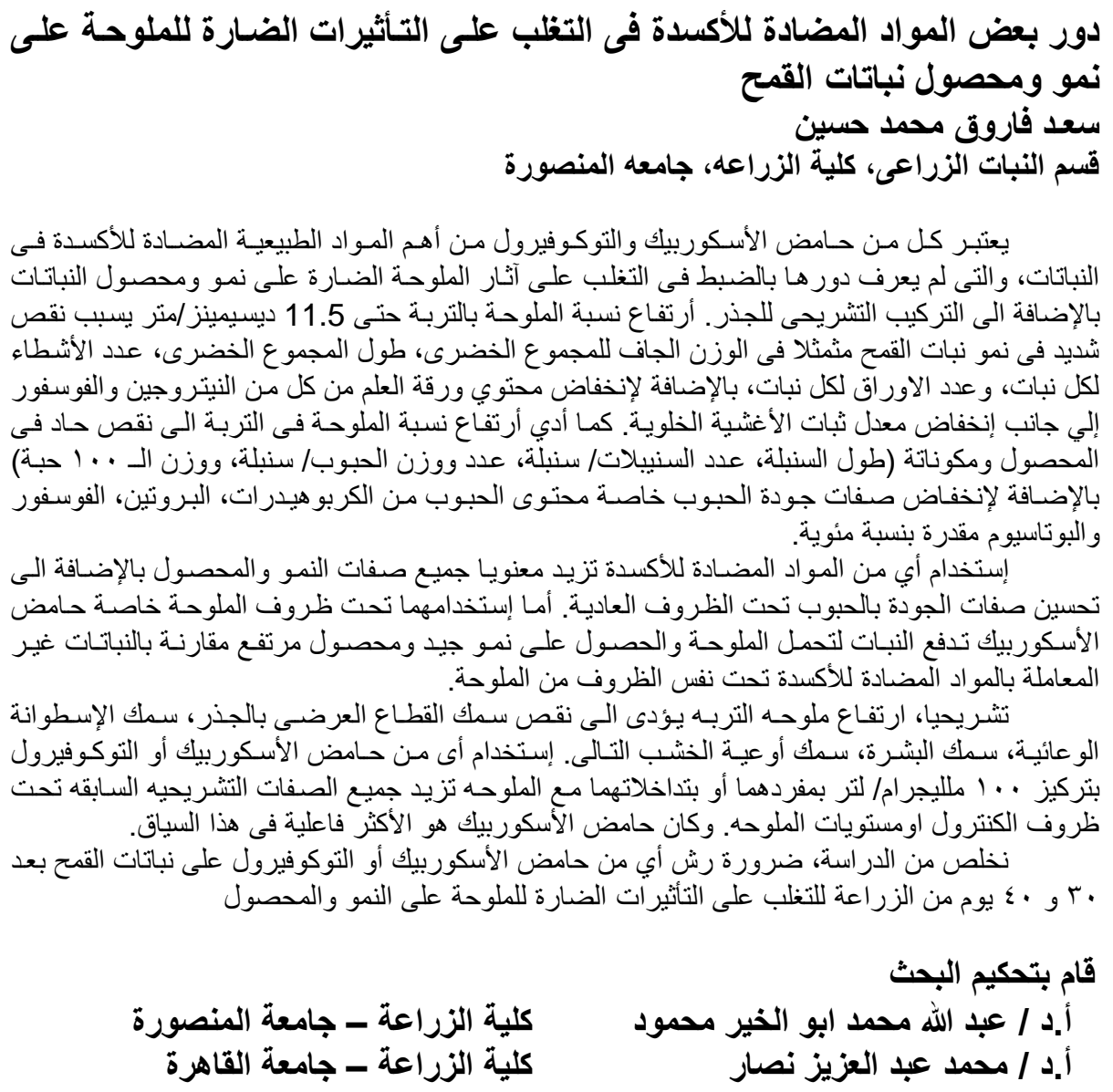

كلية الزراعة - جامعة المنصورة كلية الزراعة - جامعة القاهرة

قام بتحكيم البحث أد / محمد عبد العزيز نصار الدير 
Table 5. Nitrogen and Phosphorous content $(\mathrm{mg} / \mathrm{g} \mathrm{DW})$ as well as membrane stability index (MSI\%) of wheat flag leaf as affected by salinity with or without antioxidants in the two growing seasons at 65 days from sowing.

\begin{tabular}{|c|c|c|c|c|c|c|c|c|c|c|c|c|}
\hline \multirow{3}{*}{ Characters } & \multicolumn{12}{|c|}{ First seasom } \\
\hline & \multicolumn{12}{|c|}{ Antioxidants (B) } \\
\hline & \multicolumn{4}{|c|}{ Nitrogen } & \multicolumn{4}{|c|}{ Phosphorous } & \multicolumn{4}{|c|}{ MSI } \\
\hline Salinity $\left(\mathrm{dSm}^{-1}\right)(\mathrm{A})$ & 0 & AsA & $\alpha$-Toc & Mean & 0 & AsA & $\alpha$-Toc & Mean & 0 & AsA & $\alpha$-Toc & Mean \\
\hline Control $(0.12)$ & 40.70 & 61.28 & 51.55 & 51.17 & 3.80 & 5.84 & 5.46 & 5.03 & 24.73 & 25.25 & 25.61 & 25.19 \\
\hline 7.5 & 34.74 & 46.57 & 39.12 & 40.14 & 3.10 & 5.32 & 3.37 & 3.93 & 11.83 & 19.69 & 14.99 & 15.50 \\
\hline 11.5 & 26.28 & 33.20 & 29.57 & 28.68 & 1.62 & 3.72 & 2.37 & 2.57 & 9.68 & 10.63 & 13.74 & 13.35 \\
\hline Mean & 33.90 & 47.01 & 40.08 & & 2.84 & 4.96 & 3.73 & & 15.41 & 20.52 & 18.11 & \\
\hline LSD 5\% & $\begin{array}{c}A \\
2.36\end{array}$ & $\begin{array}{c}B \\
2.34\end{array}$ & $\begin{array}{c}A B \\
4.06\end{array}$ & & $\begin{array}{c}A \\
0.288\end{array}$ & $\begin{array}{c}B \\
0.285\end{array}$ & $\begin{array}{c}A B \\
0.499\end{array}$ & & $\begin{array}{c}A \\
0.581\end{array}$ & $\begin{array}{c}\text { B } \\
0.584\end{array}$ & $\begin{array}{c}A B \\
1.007\end{array}$ & \\
\hline & \multicolumn{12}{|c|}{ Second season } \\
\hline Control (0.12) & 40.52 & 65.92 & 61.40 & 55.94 & 3.73 & 5.03 & 4.20 & 4.32 & 24.34 & 26.00 & 25.50 & 25.28 \\
\hline 7.5 & 32.55 & 54.84 & 48.46 & 45.28 & 2.92 & 4.05 & 3.37 & 3.44 & 11.08 & 19.55 & 15.40 & 15.34 \\
\hline 11.5 & 28.88 & 41.98 & 31.76 & 34.20 & 1.10 & 2.94 & 2.33 & 2.12 & 7.68 & 16.63 & 13.77 & 12.69 \\
\hline Mean & 33.98 & 54.24 & 47.20 & & 2.58 & 4.00 & 3.30 & & 14.36 & 20.72 & 18.22 & \\
\hline LSD 5\% & $\begin{array}{c}A \\
1.336\end{array}$ & $\begin{array}{c}\mathrm{B} \\
1.360\end{array}$ & $\begin{array}{c}A B \\
2.33\end{array}$ & & $\begin{array}{c}A \\
0.160\end{array}$ & $\begin{array}{c}\mathrm{B} \\
0.151\end{array}$ & $\begin{array}{c}A B \\
0.276\end{array}$ & & $\begin{array}{c}A \\
0.502\end{array}$ & $\begin{array}{c}\mathrm{B} \\
0.500\end{array}$ & $\begin{array}{c}A B \\
0.8665\end{array}$ & \\
\hline
\end{tabular}

Table 6. Spike length $(\mathrm{cm})$, number of spiklets per spike and grain number per spike of wheat plant as affected by salinity with or without antioxidants in the two growing seasons.

\begin{tabular}{|c|c|c|c|c|c|c|c|c|c|c|c|c|}
\hline \multirow{3}{*}{ Characters } & \multicolumn{12}{|c|}{ First seasom } \\
\hline & \multicolumn{12}{|c|}{ Antioxidants (B) } \\
\hline & \multicolumn{4}{|c|}{ Spike length } & \multicolumn{4}{|c|}{ Number of spiklets per spike } & \multicolumn{4}{|c|}{ Grain number per spike } \\
\hline Salinity $\left(\mathrm{dSm}^{-1}\right)(\mathrm{A})$ & 0 & AsA & $\alpha$-Toc & Mean & 0 & AsA & $\alpha$-Toc & Mean & 0 & AsA & $\alpha-$ Toc & Mean \\
\hline Control (0.12) & 10.33 & 10.86 & 10.53 & 10.57 & 19.00 & 21.00 & 20.00 & 20.00 & 68.66 & 84.33 & 71.00 & 74.66 \\
\hline 7.5 & 9.63 & 10.73 & 10.17 & 10.17 & 15.00 & 20.66 & 17.00 & 17.55 & 61.00 & 79.00 & 65.00 & 68.33 \\
\hline 11.5 & 5.26 & 7.83 & 6.63 & 6.57 & 7.33 & 12.00 & 10.33 & 9.88 & 27.66 & 51.00 & 39.00 & 39.22 \\
\hline Mean & 8.40 & 9.80 & 9.11 & & 13.77 & 17.88 & 15.77 & & 52.44 & 71.44 & 58.33 & \\
\hline \multirow[t]{2}{*}{ LSD 5\% } & $\begin{array}{c}A \\
0.216\end{array}$ & $\begin{array}{c}\mathrm{B} \\
0.234\end{array}$ & $\begin{array}{c}A B \\
0.374\end{array}$ & & $\begin{array}{c}A \\
0.823\end{array}$ & $\begin{array}{c}\mathrm{B} \\
0.808\end{array}$ & $\begin{array}{c}\mathrm{AB} \\
1.400\end{array}$ & & $\begin{array}{c}A \\
3.30\end{array}$ & $\begin{array}{c}B \\
3.31\end{array}$ & $\begin{array}{l}\text { AB } \\
\text { NS }\end{array}$ & \\
\hline & \multicolumn{12}{|c|}{ Second season } \\
\hline Control (0.12) & 10.36 & 11.20 & 10.56 & 10.70 & 20.00 & 23.00 & 20.60 & 21.20 & 69.66 & 87.00 & 75.33 & 77.33 \\
\hline 7.5 & 9.83 & 10.56 & 9.96 & 10.11 & 16.66 & 21.00 & 18.66 & 18.77 & 62.33 & 81.33 & 67.00 & 70.22 \\
\hline 11.5 & 5.40 & 8.86 & 6.96 & 7.07 & 8.00 & 14.00 & 11.00 & 11.00 & 28.33 & 59.00 & 42.00 & 43.11 \\
\hline Mean & 8.53 & 10.20 & 9.16 & & 14.88 & 19.33 & 16.75 & & 53.44 & 75.77 & 61.44 & \\
\hline LSD 5\% & $\begin{array}{c}A \\
0.409\end{array}$ & $\begin{array}{c}\mathrm{B} \\
0.407\end{array}$ & $\begin{array}{c}A B \\
0.714\end{array}$ & & $\begin{array}{c}A \\
0.785\end{array}$ & $\begin{array}{c}\mathrm{B} \\
0.776 \\
\end{array}$ & $\begin{array}{c}\mathrm{AB} \\
1.361\end{array}$ & & $\begin{array}{c}A \\
1.99\end{array}$ & $\begin{array}{c}B \\
2.00 \\
\end{array}$ & $\begin{array}{c}\mathrm{AB} \\
3.46 \\
\end{array}$ & \\
\hline
\end{tabular}

